\title{
A Comparative Reading of Sejanus and Cato*
}

\author{
Hui Guo 1,2, Qing Wang3 \\ ${ }^{1}$ Visiting Scholar to the English Department of Harvard University, Cambridge, USA \\ ${ }^{2}$ English Department of Hebei University of Engineering, Handan, China \\ ${ }^{3}$ School of Public Administration, University of International Business and Economics, Beijing, China \\ Email: tea2010@163.com, russiacn@163.com
}

Received 2 January 2015; accepted 27 March 2015; published 31 March 2015

Copyright (C) 2015 by authors and Scientific Research Publishing Inc.

This work is licensed under the Creative Commons Attribution International License (CC BY). http://creativecommons.org/licenses/by/4.0/

(c) () D Den Access

\begin{abstract}
It seems that William Shakespeare's Macbeth bears more similarities to Ben Jonson's Sejanus. However, the two tragedies are even more different than Joseph Addison's Cato and Jonson's Sejanus as in Macbeth witchcraft and violent murder are involved. And Macbeth's wife is even more vicious than the protagonist. Undeniably, there are more differences between Ben Jonson's Sejanus and Joseph Addison's Cato. The themes are different as Jonson's Sejanus focuses on the protagonist's conspiracy to the emperor Tiberius while Addison's Cato praises the hero's nobility and wisdom, though both die in the end of the tragedies. Triangular love is woven and being one of the main themes in Cato while adultery takes a small portion in Sejanus. Despite of the differences in these two tragedies, and the fact that the two dramatists belong to different eras, there are five main similarities between them: both tragedies being entitled with their protagonists' names and setting in the ancient Rome, traitor ministers and conspiracy taking great proportion in the plots, the falls of the traitors in both tragedies, and the conflicts between the noble and evil parties. One can hardly fail to observe the judgments of the heroes by the characters within the tragedies. These similarities between the themes and structures of the plots lead to the similarities between the portrayals of the characters. Both Sejanus and Cato are heroic plays and political tragedies of Rome. The textual comparison between these two tragedies reveals an obvious influence of Jonson to Addison, who is also creative and develops this type of tragedy with the plot of triangular love.
\end{abstract}

\section{Keywords}

Heroic Plays, Political Tragedies, Sejanus, Cato, Traitor, Noble

\footnotetext{
*Thanks to CSC for the scholarship granted to Hui Guo to Harvard University, and to Yun Ni, who has helped with some of the references.
} 


\section{Introduction}

Ben Jonson's Sejanus was said to have been mainly written before Queen Elizabeth I's death and first performed at Globe Theatre in 1603 (Cain, Bevington, \& Donaldson, II, 2012: p. 203). It was "hissed off the stage” probably without a second performance (Jonson, Herford \& Simpson, IX, 1950: p. 190). Tom Cain discussed the court of Tiberius in the play parallels to that of Elizabeth I's and James I, especially the former's (ibid). Sejanus, the Caesar Tiberius's favorite, tried to kill the Caesar's heirs and noble courtiers for the absolute power of the nation.

If Jonson turned to tragedy due to his failure in his creation of popular comedies, Addison's creation of Cato owed to his attendance of an Italian farce of Cato when he traveled to Italy in 1703 according to Macaulay (Walker, 1900: p. 28). But till 1713 Cato had its last form because of the "urgency of [Addison']s political friends”, as they "hoped that the public would discover some analogy between the followers of Caesar and the Tories, between Sempronius and the apostate Whigs, between Cato, struggling to the last for the liberties of Rome” (Walker, 1900: p. 77). Thus in the tragedy, Cato is portrayed as a leader and fighter against the tyranny of Caesar. However, the hero chooses to commit suicide at the end of the play where he thinks that there is no hope to achieve his goal and he would rather die than surrender. The play was given to Drury Lane Theatre for performance.

It seems that William Shakespeare's Macbeth is more similar to Ben Jonson's Sejanus. However, the two tragedies are even more different than Joseph Addison's Cato and Jonson's Sejanus as in Macbeth witchcraft and violent murder are involved. And Macbeth's wife is even more vicious than the protagonist. Undeniably, there are more differences between Ben Jonson's Sejanus and Joseph Addison's Cato. Among the $18^{\text {th }}$ century tragedies included in British Dramatists from Dryden to Sheridan, Joseph Addison's Cato is the one which resembles to Ben Jonson's Sejanus most. Dryden's Conquest of Granada and All for Love are more or less tragedies of military and love conquests, and the love stories more likely involve the monarchs which is dissimilar to Sejanus, where there is scarcely a love scene and the love is between the minister and the wife of the prince, rather than between the sovereigns or between a sovereign and a subject ${ }^{1}$. Although Sejanus and Cato were written in different times by different dramatists, they bore some similarities. This essay will focus on these two questions: first, what are the similarities between Jonson's Sejanus and Addison's Cato? Second, what do the similarities mean?

\section{Literature Review}

George Chapman, John Marston and Edmund Bolton were the first critics who speak highly of Sejanus from 1605 to 1621 (Craig, 1995: p. 97). But Leonard Digges made his criticism of Sejanus in his poem with this verse, “Sejanus too was irksome” (Craig, 1995: p. 162). C. H. Herford and Percy Simpson, David Bevington, Martin Butler and Ian Donaldson are the most influential modern critics of Jonson's Sejanus and balanced views are included in the introductions of the tragedy they edited in their versions of Jonson's works. Fairly speaking, Bevington, Butler and Donaldson's edition of Jonson offers a more balanced and elaborate view than that of Herford and Simpson, who believe Jonson ridiculed his contemporaries with this tragedy, though they first narrate the story of Jonson being accused of “popery and treason” by the Earl of Northampton (Jonson, Herford, \& Simpson, I, 1925: p. 36-37). Tom Cain asserts that Jonson’s Sejanus is the very tragedy that helps us perceive later Roman plays by the English dramatists (Cain, Bevington, \& Donaldson, II, 2012: p. 197)². Cain also discusses the parallel of Tiberius' court to that of Elizabeth I in addition to the introduction of the exact date and reception of the first performances of the play. Jennifer Dawn Jones (2005), one of the modern critics of Sejanus, discusses exclusively the complex portrayal of characters in the tragedy in her MA dissertation Complexity of Character in Jonson's Sejanus. Some of her comments are instructive, such as her discussion of Jonson's portrayal of the protagonist and the truthfulness of the play to the history.

Like Jonson’s Sejanus, Addison’s Cato draws few critics than his essays. Alexander Pope is the first favored

\footnotetext{
${ }^{1}$ It seems that Shakespeare's Macbeth bears more similarities to Jonson's Sejanus. However, the two tragedies are even more different than Addison's Cato to Jonson's Sejanus as in Macbeth witchcraft and violent murder are involved. And Macbeth's wife is even more vicious than the protagonist. Although in Dryden's All for Love the love between Anthony and Cleopatra is undeniably adultery like that between Sejanus and Livia, the former pair's adultery seems to be fairly moving and beautiful while the latter's rather shameful and malicious. I think it is partly due to Dryden's weaving and partly due to different identities of the lovers between the two tragedies: Anthony and Cleopatra belong to the ruling class, or rather to the peak of the social hierarchy—monarchs, while Sejanus and Livia are inferior to them, and their love is to work together like the Macbeths to murder the authority before being empowered as monarchs. In contrast, Cleopatra's love for Anthony is to hold her country to her instead of being conquered by the Romans.

¿“[W]ithout Sejanus it is difficult to see Sejanus's later Roman plays including King Lear and Macbeth Poetaster corrosive effects of flattery envy, and detraction, false accusation of treason, spies, informers and censorship” (Cain, Bevington, \& Donaldson, II, 2012: p. 197).
} 
critic of Cato as he composed the prologue for the tragedy. And Macaulay is another influential critic who investigates the background, creation dates, performances and reception of Cato, in addition to the favored comment that the play is "certainly above any other English tragedy of the same school" and even better than "many of the plays of Corneille" (Walker, 1900: p. 80). Macaulay also includes John Dennis's criticism of the play and thinks it "literary envy" (ibid). Following Dennis, Jorge Bastos de Silva deprecates Cato's heroism in his essay "Cato's Ghosts: Pope, Addison, and Opposition Cultural Politics," and analyzes the tragedy in the political context of Addison's age ${ }^{3}$. Silva asserts that Cato is not really a pursuer of liberty or fighter against the so-called tyranny Caesar for his suicide is in fact the give-up of his pursuit and the captive of his "ruling passion" (de Silva, 2005: p. 98). George. H. Nettleton, Arthur E. Case and George Winchester Stone are important modern critics who think the sentiment of the tragedy "pure and noble," and the play follows "academic, neoclassical traditions" for the "unities of time and place are observed" (Nettleton, 1969: p. 473). But they criticize the play for its "didacticism" and "lack of dramatic movement," "coldness," and "strong admiration for the moral strength of the hero" (ibid). Laura J. Rosenthal believes that the romance between Juba and Marcia, Cato's daughter has a greater meaning than the main theme led by the protagonist and lands the tragedy on a less heroic base. Thus, she claims that "the promised marriage between Juba and Marcia in many ways defines a significant alternative to the conflict between Caesar and Cato" and Cato "places nationalism in tension with Enlightenment cosmopolitanism" (Rosenthal, 1999: p. 64). Filipowicz (2010) in her essay "School for Patriots? the Foundational Dramas of the American and Polish Revolutions Revisited" approaches Addison's Cato by analyzing the theme of patriotism and believes that the patriotic theme in Anna Bojarska's play Lebzja Polsbego (The Polish Lesson) were influenced by Addison's Cato, in which the protagonist fought against the tyrannical Caesar for liberty.

As this review shows, the comparison between Jonson's Sejanus and Addison's Cato is not yet touched by previous critics in the concerned field. The following part is the comparison of the two tragedies in detail.

\section{Similarities between Jonson's Sejanus and Addison's Cato}

\subsection{Both Tragedies Entitled with the Key Figure's Name}

As the titles of Jonson's and Addison's tragedies suggest, Sejanus and Cato are not only the real historical names of Rome but also the names of the protagonists in the plays. Undeniably, Dryden's All for Love also involves the historical names of the historical characters like Caesar, Antonius, and Cleopatra and so on, but the play is not entitled after the historical names of the characters. Thematically speaking, All for Love is quite different from Sejanus, where political power is far more important and takes larger portion in the play than love. The other tragedies are either not entitled after the key figures in the plays or not entitled after the Roman historical characters.

\subsection{Both Tragedies Involving Traitor Ministers}

In Dryden's Conquest of Granada, traitor ministers are also involved. But interestingly, Prince Abdalla's purpose of seeking the throne is for winning the love of Lyndaraxa, right contrary to Sejanus', who seeks Livia's love for murdering the prince Drusus, or in other words, for seeking political power ${ }^{4}$. To me, there is no traitor to Antonius or to Cleopatra. Or if there is, it is Caesar.

Both plots of Jonson's Sejanus and Addison's Cato involve traitor ministers. And in either of the tragedies, the traitor is not alone. In Sejanus, Sejanus has his followers, like Satrius, Eudemus, Livia, Natta, and so on. And there is even a counterpart of Sejanus, Macro, whose role is similar to Sejanus, set by the Caesar Tiberius. In Macro's soliloquy, we learn that he is by no means a loyal minister.

It is the bliss

Of courts to be employ'd, no matter how;

\footnotetext{
${ }^{3}$ Quoting Pope and Dennis, Silva believes the play insinuates the contention between the Whig and the Tories.

${ }^{4}$ Also, the wooing of Prince Abdalla to Lyndaraxa is normal between two unmarried persons while Sejanus' wooing to Livia is adultery as the latter is married. The other "traitors" portrayed in Dryden's Conquest of Granada are probably Boabdelin and Almanzor. This accusation involves their love for the future queen Almahide. She is the fiancée to the king Boabdelin, who would not sacrifice her to thank his savior Almanzor. To this point, Boabdelin is a traitor to Almanzor's bravery and kindness. Or he might be unable to restore his sovereignty and might lose his life as Lyndaraxa forces Abdalla to clear the way for his throne. But when Boabdelin learns the affair between Almahide and Almanzor, he thought the latter is a traitor, and even intends to shame and torture or even to kill Almanzor (Act V Scene III). It is Almahide who compromises to marry the king but on condition that he lets go the Achillies-like hero.
} 
A prince's power makes all his actions virtue [...]
The way to rise is to obey and please.
He that will thrive in state, he must neglect
The trodden paths that truth and right respect;
And prove new, wilder ways: for virtue there
Is not that narrow thing, she is elsewhere [...]
If then it be the lust of Caesar's power,
To have raised Sejanus up, and in an hour
O'erturn him, tumbling down, from height of all;
We are his ready engine: and his fall
May be our rise. It is no uncouth thing
To see fresh buildings from old ruins spring (3.3: 93-95, 113-117, 125-127; Kidnie, 2000: p. 172-173).

From the quotation above, Macro's intention is obvious, to obtain the profit from Sejanus' fall and to rise in power himself, though he has few followers in the play.

In Addison's Cato, the traitor ministers are Sempronius and Syphax, though they are not like Sejanus as the protagonist in the tragedy, and inferior to Cato's role. Still, they are important characters in the tragedy, not only because they help set off Cato's nobility but because they enrich the plot throughout the previous four acts of the tragedy. Syphax is the main follower of Sempronius.

Thus, in both Sejanus and Cato, we read the struggles between the noble and evil camps. The characters in one camp helps set off the other.

\subsection{Falls of Both Traitor Ministers in the Tragedies}

Sejanus falls in the last act in the tragedy while Sempronius and Syphax fall in the fourth act of Cato. Neither of them is successful in obtaining their original goals. Sejanus intends to seize the throne by murdering the prince, framing Augusta, and other noble ministers for treason. Nevertheless, Tiberius does not wait for Sejanus' rise too much before setting to work for his fall. Thus, in Act V, Scene X, we read the condemnation of Sejanus in front of the senators, among whom none is a friend of him, even Cotta, who once states "my lord Sejanus," calls for "[t]o the dungeon with him” (5.7: 8, Kidnie, 2000: 204; 5.10: 204, Kidnie, 2000: p. 214).

Sempronius plans to surrender to Caesar and conspires against Cato, who thwarts the former's conspiracy with his nobility. The second goal of Sempronius is to kidnap Marcia, daughter of Cato he loves. Nevertheless, Juba, the Numidian prince comes to the scene where Sempronius disguises in the prince's garment. Needless to say, he is killed on the spot. Both Sempronius and his follower Syphax end their lives disgracefully in Act IV instead of the last act as Sejanus, still near the ending of the tragedy. This difference tells the different types of the protagonists the two tragedies include.

Both evil parties in the two tragedies are partially successful. Sejanus succeeds in accusing the loyal parties (such as Silius, Agrippina, Drusus) of treason, obtaining the evil physician Eudemus' help and winning over Livia's love. Sempronius is successful at first to cheat the military leaders and plot a mutiny against Cato. He is also successful in killing the leaders. Syphax is successful to persuade Juba to betray Cato at first.

\subsection{Contrasts between the Noble and Evil Parties in the Tragedies}

In Jonson's Sejanus, the contrast between the ending statements of the noble party Silius, Sabinus, and the evil party Sejanus is worth mentioning.

Silius Stay, most officious senate, I shall straight

Delude thy fury. Silius hath not placed

His guards within him, against fortune's spite,

So weakly, but he can escape your gripe

That are but hands of fortune: she herself,

When virtue doth oppose, must lose her threats!

All that can happen in humanity,

The frown of Caesar, proud Sejanus' hatred,

Base Varro's spleen, and Afer's bloodying tongue, 
The senate's servile flattery, and these

Muster'd to kill, I'm fortified against;

And can look down upon: they are beneath me.

It is not life whereof I stand enamour'd;

Nor shall my end make me accuse my fate.

The coward and the valiant man must fall,

Only the cause and manner how, discerns them:

Which then are gladdest, when they cost us dearest.

Romans, if any here be in this senate,

Would know to mock Tiberius' tyranny,

Look upon Silius, and so learn to die. [Stabs himself (3.1: 320-339, Kidnie, 2000: p. 161)

Sabinus Spies of this head, so white, so full of years!

Well, my most reverend monsters, you may live

To see yourselves thus snared. [...]

You do well,

My most officious instruments of state;

Men of all uses: drag me hence, away.

The year is well begun, and I fall fit

To be an offering to Sejanus. Go! [...]

It shall not need. Forbear your rude assault.

The fault's not shameful, villainy makes a fault. [Exeunt. (4.3: 128-140, Kidnie, 2000: p. 180)

Sejanus Have we no friends here? [...]

Is Macro here?

O, thou art lost, Sejanus!

Silius' and Sabinus' words display their righteousness and nobility, though they meet their endings being snared unexpectedly. They are intrepid and poised. While Sejanus meets his ending with some sort of preview and desperately seeks help from his so-called faction. Unlike Silius and Sabius, these last words of Sejanus reveal that he knows that he deserves such ending.

In Addison's Cato, there is the contrast between the deaths of the evil party Sempronius, Syphax and the noble party Cato. The former two are killed by the loyal party, Sempronius is killed by Juba, and Syphax killed by Marcus, while Cato, like Silius in Jonson's Sejanus, most extolled in the play, commits suicide. And the difference between their suicides is that Silius has some bombastic speech before the action while Cato's is found after his death.

\subsection{Judgments of the Protagonists by the Characters within the Tragedies}

Limited by the length of the dramatic text which is considerably shorter than that of a novel, the playwrights might resort to the other characters to fill in the gaps where the direct portrayals of the protagonists might lack. And the words of the other characters (including chorus) within the plays seem to be trustworthy to the reader or the audience.

In Jonson's Sejanus, Arruntius is a cool observer who observes and comments on the characters including Sejanus, the protagonist's deeds.

Arruntius Two of Sejanus' blood-hounds, whom he breeds

With human flesh, to bay at citizens (3.1: 376-377, Kidnie, 2000: p. 163).

Arruntius Still dost thou suffer, heaven! will no flame,

No heat of sin, make thy just wrath to boil

In thy distemper'd bosom, and o'erflow

The pitchy blazes of impiety,

Kindled beneath thy throne! Still canst thou sleep,

Patient, while vice doth make an antick face

At thy dread power, and blow dust and smoke 
Into thy nostrils! Jove! will nothing wake thee?

Must vile Sejanus pull thee by the beard,

Ere thou wilt open thy black-lidded eye,

And look him dead? Well! snore on, dreaming gods,

And let this last of that proud giant-race

Heave mountain upon mountain, 'gainst your state (4.5: 1-13, Kidnie, 2000: p. 181-182)

Arruntius' comment of the personality of Sejanus is convincing and appealing to the reader or to the audience as he is one of the characters in the play rather than the dramatist who is outside of the text.

In Cato, the protagonist is constantly commented by his family, and senators, even the Numidian prince Juba. Even in the first scene of the first act, in answering to Marcus' doubt, Portius thus comments his father:

Portius [...] How does the lustre of our father's actions,

Through the dark cloud of ills that cover him,

Break out, and burn with more triumphant brightness!

His sufferings shine, and spread a glory round him;

Greatly unfortunate, he fights the cause

Of honour, virtue, liberty, and Rome.

His sword ne'er fell, but on the guilty head;

Oppression, tyranny, and pow'r usurp'd,

Draw all the vengeance of his arm upon them (I.I: 27-35, Nettleton, 1969: p. 477).

Lucius is a senator in Cato's court and addresses to Marcia after they know it is impossible to drive Caesar's force back:

Lucius Sweet are the slumbers of the virtuous man!

Oh, Marcia, I have seen thy godlike father!

Some power invisible supports his soul,

And bears it up in all its wonted greatness (V. IV: 27-30, Nettleton, 1969: p. 497).

Here the phrases "virtuous man," "godlike father" and "his soul [...] its wonted greatness" obviously raise a holy halo around Cato. Juba, having admired Cato, thus retorts Syphax's enticing him to betray Cato:

Turn up thy eyes to Cato;

There may'st thou see to what a godlike height

The Roman virtues lift up mortal man.

While good, and just, and anxious for his friends,

He's still severely bent against himself;

And when his fortune sets before him all

The pomps and pleasures that his soul can wish,

His rigid virtue will accept of none (I. IV: 49-58, Nettleton, 1969: p. 480).

From the judgments of the characters within the tragedies, the reader, especially the audience, is able to form clear images of the protagonists of the tragedies instantly. It is also a way for the dramatists to colorize the images of the protagonists.

\subsection{Humans Instead of Character Types Portrayed in Both Tragedies}

In Sejanus, Jonson intends to depict the protagonist as a human instead of the character type in the ancient plays. In the motto of the title page of the tragedy, Jonson quotes from Martial Verse 4, Book X 'You won't find Centaurs here or Gorgons or Harpies: my page smacks of humanity (non hic centauros, non Gorgonas Harpyiasque/ invenies: hominem pagina nostra sapit 1l. 9-10)" (Martial, II, 1993: p. 328). It is evident that Jonson aims to represent the protagonist as a lifelike human. Thus, we see Sejanus physically normal as a human, though mentally distorted by his life experience and living environment. In the tragedy, there is no monster like the one in his comedy The Devil Is an Ass, or gender transformation in Epicoene: the Silent Woman. Being favored by Tiberius, the Caesar, Sejanus intrigues with Livia, Drusus' wife and the doctor Eudemus to murder Drusus and grab power which he believes will bring him happiness. Tom Cain claims that the play involves a "humanist 
concept of a responsible citizenship” (Cain, Bevington, \& Donaldson, II, 2012: p. 208). Jones' discussion of the complex character depiction in Jonson's Sejanus also verifies this point. The essayist notices that the characters are delineated as not totally "good" or "bad" (30 ff.).

Although there is no epigraph to advertise that Cato is portrayed as a human in the tragedy, Addison also endeavors to represent the hero as a human rather than a character type, less possibly a monster as Addison defines tragedy as "noblest production of human nature" (Spectator 39, 1711, qtd. in Nettleton, 1969: p. 473). Silva comments that Cato is "not a perfect example of moral qualities" and the heroism in the negative character Syphax (de Silva, 2005: p. 103). The reason why Cato is "not a perfect example" is that he is a human. It is universally acknowledged that no human is perfect. Also quoted in the previous passage in the present essay, Nettleton, Case and Stone affirm the hero's human identity by extolling the "pure and noble sentiment" of the characters, especially the hero, and by criticizing the "coldness" in addition to the praise of the "academic, neoclassical traditions" (Nettleton, 1969: p. 473). In the reality, it is not rare to find examples that would choose to die rather than to surrender to their enemies in the movies concerning World War II.

\subsection{Both Sejanus and Cato in a Corrupt Rome}

Cato (95-46 BC) and Sejanus (20 BC-31 AD) lived in the same period where corruption was rather common and serious. In Sejanus, Cato is thrice mentioned with honor: "Where is now the soule/Of god-like Cato? he, that durst be good" (i.89-90), "[t]he innocence of Cato" (i.151), "To Cicero's booke, where Cato was heau'd vp/ Equall with heau'n" (iii.427-428), respectively sighed by Arrunius and Cordus, positive characters (Jonson, Herford, \& Simpson, IV, 1932: p. 358, 407). Their time was one of the notorious in the history and that is why Cato is called for. Also, we read Arrunius, commenting right after his extol of Cato, "When Caesar durst be euill; and had power/ As not to liue his slaue, to dye his master?" and Cordus affirms Arrunius with these words, "what else did Caesar answere, Being then Dictator" (Jonson, Herford, \& Simpson, IV, 1932: p. 358, 407). These words remind us Cain's quotation of Holland in the introduction of the play in the Cambridge edition that the play “illuminates the general 'faults' of the times rather than specific 'men'” (Cain, Bevington, \& Donaldson, II, 2012: p. 203).

In the beginning of the tragedy, Jonson lets Arrunius tell the audience about Sejanus, who is, "A seruing boy! [...] at Caivs' trencher, when for hyre/He prostituted his abused body/To that great gourmond, fat Apicivs/And was the noted pathick of the time” (i.212-6, Jonson, Herford \& Simpson, IV, 1932: p. 362). As Jones analyzes that the phrase "serving boy" indicates Sejanus' base identity and the term "pathick" reveals Sejanus' suffering from the upper class's or the stronger party's sexual abuses in the society. In other words, Sejanus was not born to be bad, considering his growth from sufferance.

In the first scene, Act I, Martius thus exclaims "But what can Cato do/Against a world, a base, degenerate world/That courts the yoke, and bows the neck of Caesar?” (Nettleton, 1969: p. 477). Obviously, in the tragedy Cato is in a corruptive world where he is rather lonely in contrast to Caesar, who has numerous followers. In "Cato's Ghosts: Pope, Addison, and Opposition Cultural Politics," Silva asserts that "Cato stands for the idea of a Rome that no longer exists—not on account of Caesar's victories but because the Roman people have become corrupt” (de Silva, 2005: p. 100). As discussed before, Sejanus' Rome is also said to be very corruptive.

\section{Differences between the Two Tragedies}

Differences between the two tragedies are obvious and more. Here are the chief examples.

In Jonson's Sejanus, love takes a very small portion and is an equivalent of adultery (Sejanus' love to Livia), while in Addison's Cato, love is one of the important themes. And there are two paralleled 3-party love affairs between the characters. Lucia is loved by two sons of Cato, Portius and Marcus, and Marcia loved by Juba and Sempronius. Both Marcus and Sempronius love their ladies out of great and uncontrollable passion. And Lucia's

\footnotetext{
${ }^{5}$ Like Addison's Cato, Dryden also includes two pair of triangle love in the tragedy. Lyndaraxa is loved by Prince Abdalla and Abdelmelech chief of the Abencerrages, and Almahide loved by the king and Almanzor. The similarity is that either Sempronius or Boabdelin is an unworthy lover to Marcia or to Almahide, though the social ranks of the lovers are different between the two tragedies. But to me, there are mainly three differences: 1) Lyndaraxa is an unworthy lady to be loved, as Abdalla tries in vain, and in fact, his love for her traps himself in the difficult situation as a traitor, while both Lucia and Marcia are worthy loving; 2) Lucia's lover Marcus is also a worthy lover, though she prefers to Portius', while to Almahide, Boabdelin is unworthy loving, but for saving Almanzor she agrees to marry the king; 3) Sempronius' love for Marcia is almost out of Marcia's knowledge, though she mourns him. The truth is that she thinks it is Juba rather than Sempronius, whom she mourns. In Conquest of Granada, these two ladies (Benzayda and Almahide) stand in contrast to Lyndaraxa, who loves no man but power.
} 
and Marcia's choices of their lovers reveal the age of reason ${ }^{5}$.

Also, as Addison entitles his tragedy with Cato, he intends to portray a positive character in his tragedy while Jonson's with Sejanus to draw the image of the negative character. The endings between the two tragedies are different: Cato commits suicide in the last scene and his family and people mourn their loss while Sejanus is being judged in the last scene, both positive characters like Arruntius and negative characters such as Macro are contented with the fall of Sejanus.

\section{Conclusion}

Both Sejanus and Cato are heroic plays and political tragedies of Rome, though they were produced by different dramatists in different ages in the history of English literature. The differences between them are needless to say obvious and more, but there are similarities between them which lie in the backgrounds, subjects, themes and even the way of entitling the tragedies. Both protagonists are portrayed as humans in the reality and both of them lived in the corruptive Rome. The meaning of investigating the similarities and differences between the two tragic texts is the reveal of an obvious influence of Jonson to Addison, who is also creative and develops this type of tragedy with the plot of triangular love ${ }^{6}$.

\section{References}

Addison, J. (1842). The Works of Joseph Addison (Vol. II). New York: Harper \& Brothers.

Cain, T. (2012). Introduction to Sejanus. In D. Bevington, M. Butler, \& I. Donaldson (Eds.), Ben Jonson’s Works (Vol. II). Cambridge: Cambridge UP.

Craig, D. H. (1995). Ben Jonson: The Critical Heritage. London \& NY: Routledge.

de Silva, J. B. (2005). Cato’s Ghosts: Pope, Addison, and Opposition Cultural Politics. Studies in the Literary Imagination, $38,1$.

Filipowicz, H. (2010). School for Patriots? The Foundational Dramas of the American and Polish Revolutions Revisited. Canadian Slavonic Papers, 52, 19-45.

Jones, J. D. (2005). The Complexity of Character in Jonson's Sejanus. Huntington: Marshal University.

Jonson, B. (1925). Works. In C. H. Herford, \& P. Simpson (Eds.), Vol. I. Oxford: Oxford UP.

Jonson, B. (1932). Works. In C. H. Herford, \& P. Simpson (Eds.), Vol. IV. Oxford: Oxford UP.

Jonson, B. (1950). Works. In C. H. Herford, \& P. Simpson (Eds.), Vol. IX. Oxford: Oxford UP.

Kidnie, M. J., Cordner, M., et al. (2000). Poetaster, or, The Arraignment, Sejanus His Fall, The Devil Is an Ass, The New Inn, or, The Light Heart. Oxford World's Classics. Oxford: Oxford UP.

Martial (1993). Epigrams (Vol. II). In D. R. Shackleton Bailey, Ed. Cambridge \& London: Harvard UP.

Nettleton, G. H., \& Case, A. E. (Eds.) (1969). British Dramatists from Dryden to Sheridan. Carbondale and Edwardsville: Southern Illinois UP.

Rosenthal, L. J. (1999). Juba's Roman Soul: Addison's Cato and Enlightenment Cosmopolitanism. Studies in the Literary Imagination, 32, 63-76.

Walker, A. P. (1900). Macaulay’s Essay on Addison. Heath’s English Classics. Boston: D. C. Heath.

\footnotetext{
${ }^{6}$ Addison praises Jonson's Epicoene highly in Spectator (“Epicoene, or The Silent Woman, a comedy by Ben Jonson.-It is much to be regretted that this fine comedy has for several years been totally neglected by the managers of our theatres. Unless the public taste has greatly declined from what it was. This excellent performance would certainly be more acceptable than the flippant vulgar nonsense with which we are so often annoyed from the pens of some of our modern dramatists.” Addison, II, 1842: p. 73).
} 